\title{
Early exhumation of underthrust units near the toe of an ancient erosive subduction zone: A case study from the Northern Apennines of Italy
}

\author{
Francesca Remitti ${ }^{1, \dagger}$, Maria Laura Balestrieri², Paola Vannucchi ${ }^{3,4}$, and Giuseppe Bettelli ${ }^{1}$ \\ ${ }^{1}$ Dipartimento di Scienze Chimiche e Geologiche, Università di Modena e Reggio Emilia, Largo S. Eufemia 19, 41121 Modena, Italy \\ ${ }^{2}$ CNR, Istituto di Geoscienze e Georisorse, CNR, Istituto di Geoscienze e Georisorse, U.O.S. Fiorenze, Via La Pira, 4, \\ 50121 Firenze, Italy \\ ${ }^{3}$ Dipartimento di Scienze della Terra, Università di Firenze, Via La Pira, 4, 50121 Firenze, Italy \\ ${ }^{4}$ Department of Earth Sciences, Royal Holloway University of London, Egham Hill, Egham, Surrey TW20 OEX, UK
}

\section{ABSTRACT}

Apatite fission-track (AFT) analyses were performed on 16 sandstone samples from a tectonic mélange unit exposed in three tectonic windows located near the inferred front of the early Miocene subduction system of the Northern Apennines of Italy. The tectonic windows display a block-on-block tectonic mélange present under the Ligurian Units. The mélange is formed by portions of the upper plate incorporated in the plate boundary shear zone as a consequence of a mechanism of frontal tectonic erosion during the Aquitanian (early Miocene). AFT and structural data, together with stratigraphic constraints, allow the reconstruction of a complete deformation cycle with a phase of underthrusting followed by underplating and early exhumation of the tectonic mélange. The exhumation, in particular, took place at $\sim 10-20 \mathrm{~km}$ from the original subduction front. Moreover, the analysis suggests that multiple faults were active at the same time in the frontal part of the subduction zone.

\section{INTRODUCTION}

The frontal part of a subduction zone forearc is a particularly active tectonic and sedimentary setting. In the first tens of kilometers from the deformation front, out-of-sequence thrusting, normal faulting, and mass wasting events can either coexist or alternate in time. Seismic imaging and scientific drilling of modern margins show that these are loci of different tectonic processes (von Huene and Scholl, 1991; Clift and Vannucchi, 2004): frontal accretion of the incoming plate sediments can predominate; frontal tectonic erosion of the upper plate can be the lead process; or underthrusting without material transfer between the overriding and the

${ }^{\dagger}$ E-mail: francesca.remitti@unimore.it underthrusting plates can dominate, at least at the very front of the system. These processes can also alternate in space and time in the subduction zone, possibly driven by the landward or seaward migration of the frontal thrust. Thus, the plate boundary can cut through material characterized by different compositions, lithification/metamorphic conditions, and fluid pressure. Some types of changes can directly affect fault rheology and shear strength, which are key control factors on earthquake nucleation and rupture propagation (Fagereng, 2011).

The geological evolution of forearcs and the relative timing of structure development is, therefore, a key to understanding both mass balance and seismogenic behavior of subduction zones. These two aspects of forearc tectonics are well preserved in the Northern Apennines of Italy, an ancient subduction system, now exposed onland.

We focus on a block-on-block tectonic mélange cropping out in three tectonic windows located near the inferred front of the early Miocene subduction system of the Northern Apennines of Italy. The mélange has been interpreted as an exposed portion of the Northern Apennine plate boundary shear zone because of its composition and structural position (see below). Here we use apatite fission-track (AFT) data from sandstone blocks incorporated in the tectonic mélange to reconstruct the material trajectory along the plate boundary shear zone, to constrain the maximum depth and downdip transport reached by the underthrust material, and to mark the timing of its successive exhumation.

\section{GEOLOGICAL SETTING}

\section{The Northern Apennine Plate Boundary Shear Zone}

In the Northern Apennines, the Late Cretaceous convergence of the Adria-Africa plate and the European plate led to the subduction of a western branch of the Tethys ocean (Coward and Dietrich, 1989) and the buildup of an oceanic accretionary prism, called the Ligurian accretionary prism or the Ligurian Units (Principi and Treves, 1984; Treves, 1984; Marroni et al., 2010; Molli and Malavielle, 2011).

The southwestern part of the prism is represented by the Internal Ligurian Units (of Late Jurassic to early Paleocene age). These are composed of ophiolites with their pelagic/hemipelagic and terrigenous turbidite sedimentary cover (Marroni, 1994; Marroni and Pandolfi, 1996; Marroni et al., 2002, 2010, and references therein). The northeastern part of the prism is instead formed by the offscraped and frontally accreted mud-rich sediments of the External Ligurian Units (Vannucchi and Bettelli, 2002; Bettelli and Vannucchi, 2003; Marroni et al., 2010) of Late Jurassic-Early Cretaceous to early-middle Eocene age. In the middle Eocene, the frontal part of the Ligurian oceanic accretionary prism was also formed by the offscraped pre-middle Eocene Subligurian Units (Early Cretaceous-middle Eocene) (Remitti et al., 2011), considered as deposited on the Ligurian oceanic crust or transitional crust near the Adria continental crust (Elter et al., 2003).

Frontal accretion ended in the middle Eocene (Vannucchi and Bettelli, 2002), but the Cretaceous-Eocene accretionary prism remained at the topmost level of the Apennine tectonic pile where it still is at present. From at least the early Miocene, the Ligurian prism overthrust onto the Adria continental plate and its sedimentary cover (Faccenna et al., 2001; Argnani, 2002; Molli, 2008; Vannucchi et al., 2008; Marroni et al., 2010; Molli and Malavielle, 2011).

From the early to the middle Miocene, the relative displacement between the Ligurian Units and the Adria sedimentary cover (i.e., the Tuscan and Umbrian successions; Ricci Lucchi, 1990) was accommodated along multiple thrust faults forming an interplate brittle shear zone $\sim 500$ m thick (Vannucchi et al., 2008). In the

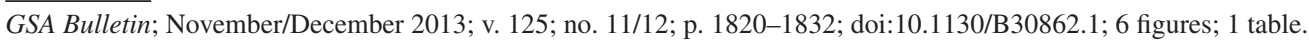


southeastern part of the Emilia Apennines, this plate boundary shear zone crops out as a regional block-on-block tectonic mélange called the Sestola-Vidiciatico tectonic unit (Remitti et al., 2007, 2012; Vannucchi et al., 2008), whereas in the northwestern part of the Emilia Apennines, it crops out as a more coherent unit, known as the Subligurian Units (Vannucchi et al., 2012) (Figs. 1 and 2). From at least the early to middle Miocene, the thrust faults in the Northern Apennine interplate shear zone (Figs. 1 and 2) were simultaneously active (Vannucchi et al., 2008), defining several overlapping thrust slices moving relatively to each other (Fig. 2). During the overriding on the subducting Adria plate, the upper plate was not involved in major tectonic structures as indicated by the mildly deformed Epiligurian Succession, i.e., the forearc slope sediment (Vannucchi et al., 2008; Remitti et al., 2012). The different blocks forming the Northern Apennine interplate shear zone mélange are made of (Remitti et al., 2007, 2011; Vannucchi et al., 2008, 2012):

(1) Cretaceous to middle Eocene deep-water sediments deposited on oceanic, transitional, and/or thinned continental crust. These sediments have been interpreted as coming from the External Ligurian Units and the pre-middle Eocene Subligurian Units, i.e., accreted units forming the Cretaceous-middle Eocene Ligurian-Subligurian accretionary prism (Vannucchi and Bettelli, 2002; Bettelli and Vannucchi, 2003). Therefore, the accretionary prism was providing material to the plate boundary shear zone (Vannucchi et al., 2008) (Fig. 2).

(2) Slope apron and thrust-top basin sediments, including mass wasting deposits (Modino succession, Porretta succession, and epi-Subligurian Units; Fig. 2) (Bettelli et al., 2002a, 2002b; Cerrina Feroni et al., 2002a; Plesi, 2002; Remitti et al., 2007, 2011). This material was deposited on the frontal part of the LigurianSubligurian oceanic prism starting from the middle Eocene (Vannucchi et al., 2012).

Most of the material in the Northern Apennine interplate shear zone derives from the toe of the overriding plate and its overlying slope deposits (Vannucchi et al., 2008, 2012; Remitti et al., 2012). Locally small (less than $100 \mathrm{~m}$ ) fragments of the Adria sedimentary cover (i.e., the footwall) are present (e.g., the Triassic evaporite rocks of the Scaglie del Secchia: see Plesi, 2002), as well as possible scrapes eroded from the base of the upper plate. Frontal tectonic erosion must be invoked to explain the incorporation of slices from the frontal part of the upper plate within the plate boundary (Vannucchi et al., 2008). The proposed model suggests that the erosion occurred through the progressive backward migration of the upper décollement
(Vannucchi et al., 2008, 2012). An alternative hypothesis suggests the underthrusting, and subsequent shearing inside the shear zone itself, of olistostrome accumulations generated at the front of the advancing upper plate (Lucente and Pini, 2008; Festa et al., 2010a).

In any case, the age of the youngest block present in the tectonic mélange gives a lower limit to the time of its incorporation in the plate boundary shear zone (Remitti et al., 2007, 2011, and references therein) (Fig. 2). A detailed reconstruction of the distribution and ages of the blocks forming this plate boundary shear zone shows that, in general, the time of the incorporation of the blocks ranges from the Aquitanian where the mélange overthrusts the internal Aquitanian-Burdigalian foredeep turbidites, to the Langhian where the mélange overthrusts the external Langhian-Serravallian foredeep turbidites (Figs. 1 and 2). Therefore, the material cropping out downdip in the plate boundary shear zone entered earlier than the material cropping out in its shallowest part.

A regional thermochronological study by Thomson et al. (2010) constrains the thermal imprint of the material cropping out in the southwesternmost sector of the Sestola-Vidiciatico tectonic unit. Data indicate that this material underthrust from the Aquitanian (early Miocene) to the Langhian (middle Miocene) and that it reached temperatures sufficient to reset the AFT system $\left(>120^{\circ} \mathrm{C}\right)$. The material was exhumed after $10 \mathrm{Ma}$, therefore after the complete deactivation of the shear zone.

In the Emilia sector of the Northern Apennines, which represents the frontal part of the overriding plate, the few available bedrock data (Thomson et al., 2010) suggest that the thermal imprint for the shallower Ligurian Units and the overlying Epiligurian Units was less than $70^{\circ} \mathrm{C}$. A detrital AFT study on the modern sands of the rivers flowing toward the Po Plain (Malusà and Balestrieri, 2012) suggests that it is likely that the deeper part of the Ligurian Units, especially in the northwestern sector of the Emilia Apennines, might be totally reset with an exhumation age between 6.5 and 4.5 Ma. No bedrock data are available on the deeper portion of the Ligurian Units and on the units below (i.e., the underthrust units such as the Sestola-Vidiciatico tectonic unit)

\section{The Three Tectonic Windows within the Ligurian Units: Nature and Composition of the Sampled Units}

In the Emilia Apennines at 10-20 km from the Ligurian deformation front, as it is preserved today, three distinct tectonic windows expose a complex structural assemblage surrounded by the External Ligurian Units and the overlying Epiligurian Succession. We refer to these three tectonic windows as the Monte Staffola, Coscogno, and Montepastore tectonic windows (Figs. 1 and 3). The outcropping complex structural assemblage is a mélange composed of kilometer-scale slices of:

(1) Cretaceous oceanic dark-gray shales with interbedded sandstone and/or micritic carbonate turbidites and varicolored shales (APA, SCB, AVV in Figs. 2 and 3); Late Cretaceous-Paleocene marls and calcareous turbidites (ELM in Figs. 2 and 3); fragments of ophiolites and ophiolitic sedimentary breccias with clasts coming from their original sedimentary cover (OPH in Figs. 2 and 3). The shale-rich slices are internally variably deformed, from folded to completely disrupted with a block-in-matrix fabric. All these components were recognized as related to the External Ligurian Units and their basement (Bettelli et al., 1989a, 1989b, 2002b; Bettelli and Panini, 1989; Panini et al., 2002).

(2) Paleocene-Eocene shales with interbedded sandstone and micritic carbonate turbidites (AVN, MSF1, MSF2 in Figs. 2 and 3) and Eocene marls and calcareous turbidites (MPA Figs. 2 and 3). They are internally deformed, from folded to completely disrupted with a block-in-matrix fabric. All these components were recognized as related to the Subligurian Units older than the middle Eocene (Papani et al., 2002; Panini et al., 2002).

(3) Decameter- to kilometer-size sparse slices of early Oligocene-early Miocene (Aquitanian)-age turbiditic sandstone and rare shale (ARB, PET, MSF3 in Figs. 2 and 3). They have been recognized as related to the Epiligurian and epi-Subligurian Units (Bettelli et al., 1989a, 1989b, 2002b; Bettelli and Panini, 1989; Capitani, 1997; Festa et al., 2010b; Gasperi and Preti, 2005; Panini et al., 2002; Papani et al., 2002).

All the various slices are out of stratigraphic order and mixed together at the map scale. Where visible their contacts are clearly represented by faults (Fig. 3) and the whole assemblage has been therefore defined as a block-onblock tectonic mélange at the map scale (blocks are of kilometric size) (the Coscogno mélange; see Bettelli and Panini, 1989; Bettelli et al., 2002b; Capitani, 1997; Gasperi and Preti, 2005).

On the basis of age, lithological characteristic, and internal state of deformation, it is possible to correlate this tectonic mélange with the Sestola-Vidiciatico tectonic unit and the Subligurian Units (Gasperi and Preti, 2005; Bettelli et al., 2002b; Panini et al., 2002; Papani et al., 2002). This correlation allows the interpretation of the tectonic mélange cropping out in the three tectonic windows as an underthrust portion of the toe of the Cretaceous-middle Eocene 


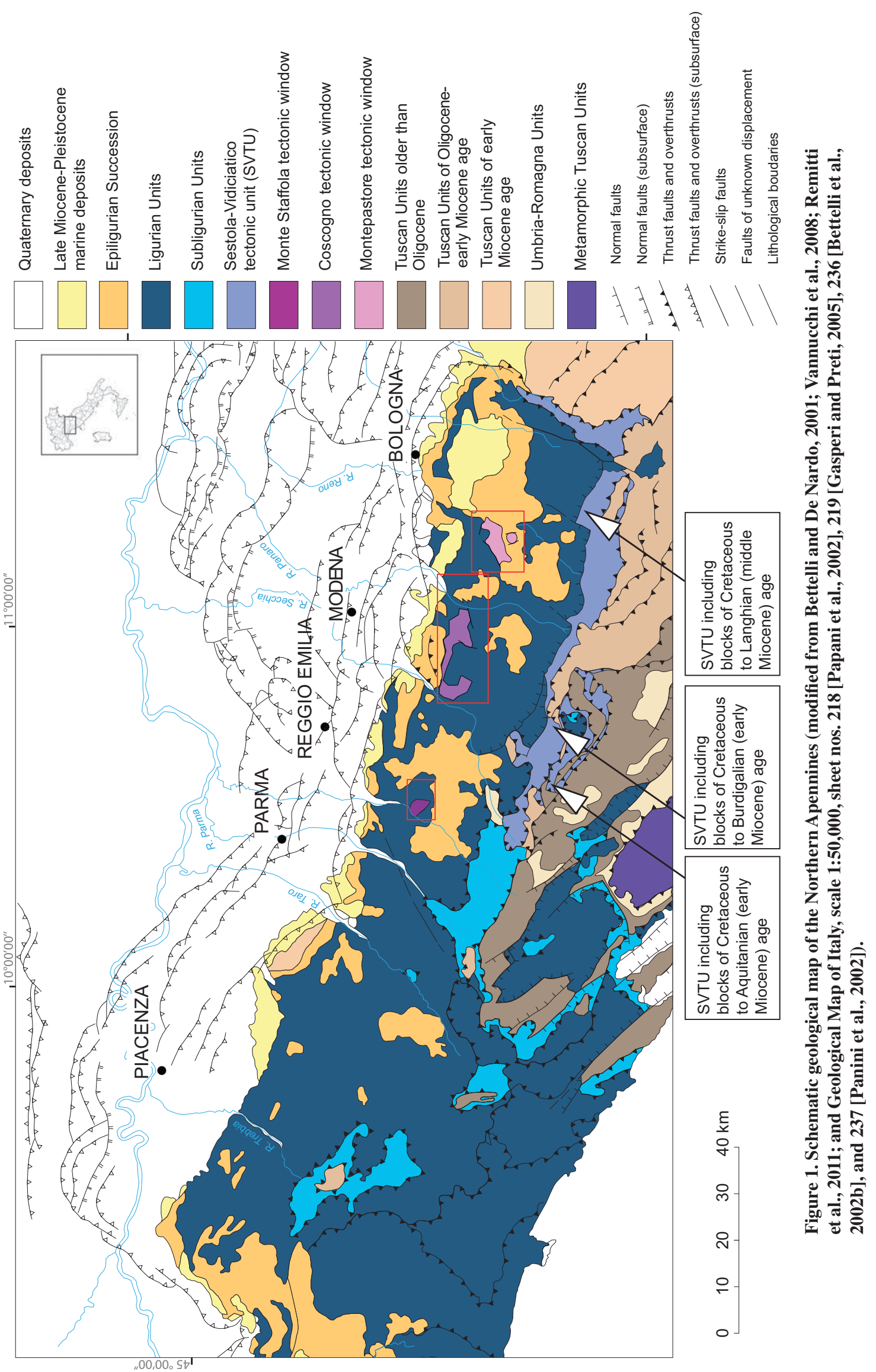



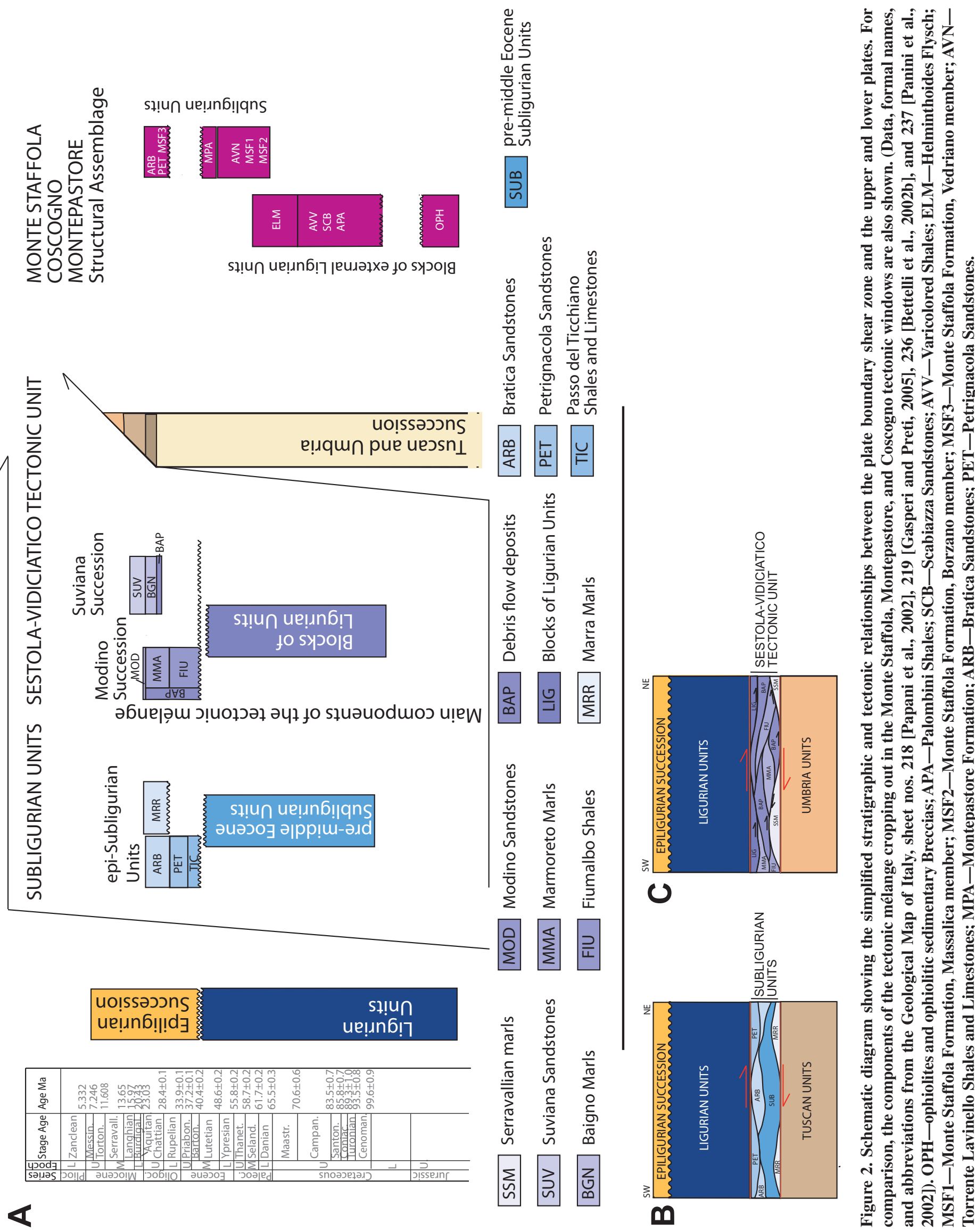

का

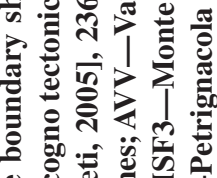

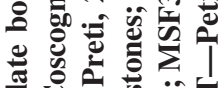
记

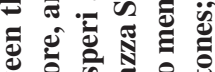

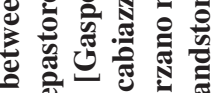
फे फ़ 至

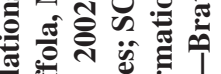
要势 की 5 का 递

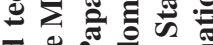

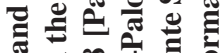

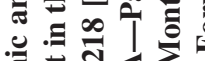

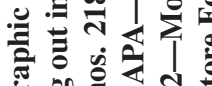

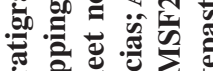
焉 要

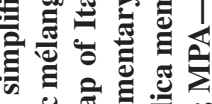

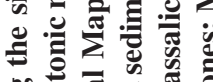

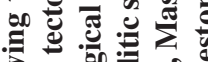

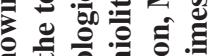

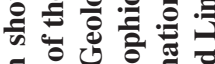

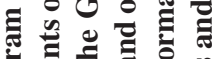
要

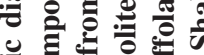
空 跣 की ن

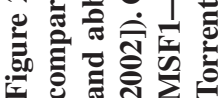


Monte Staffola tectonic window

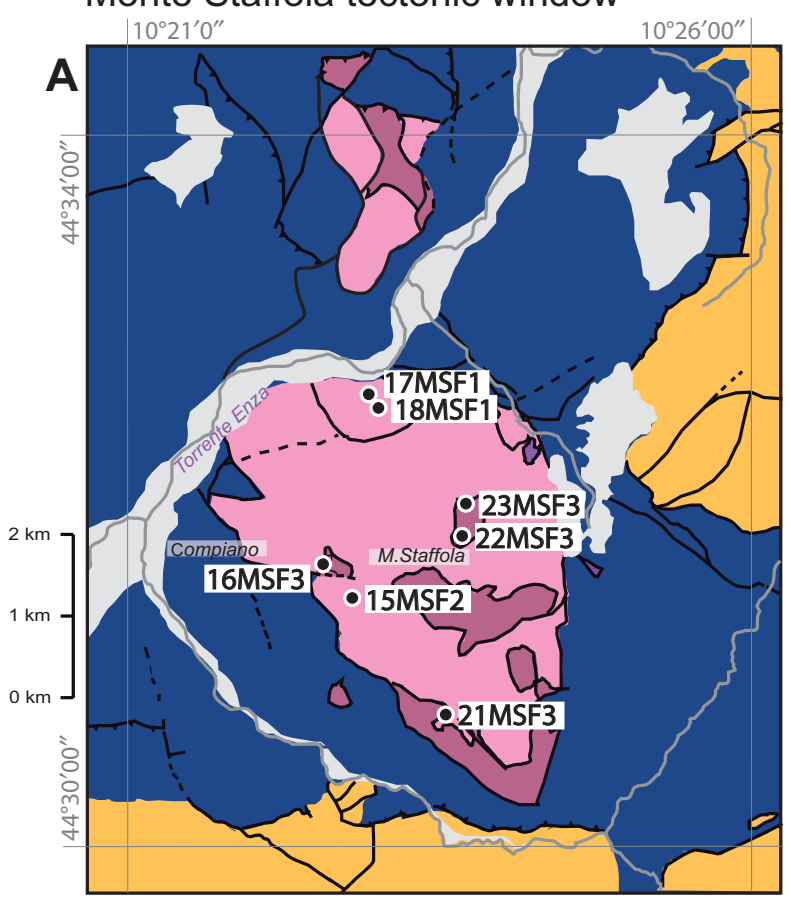

Montepastore tectonic window

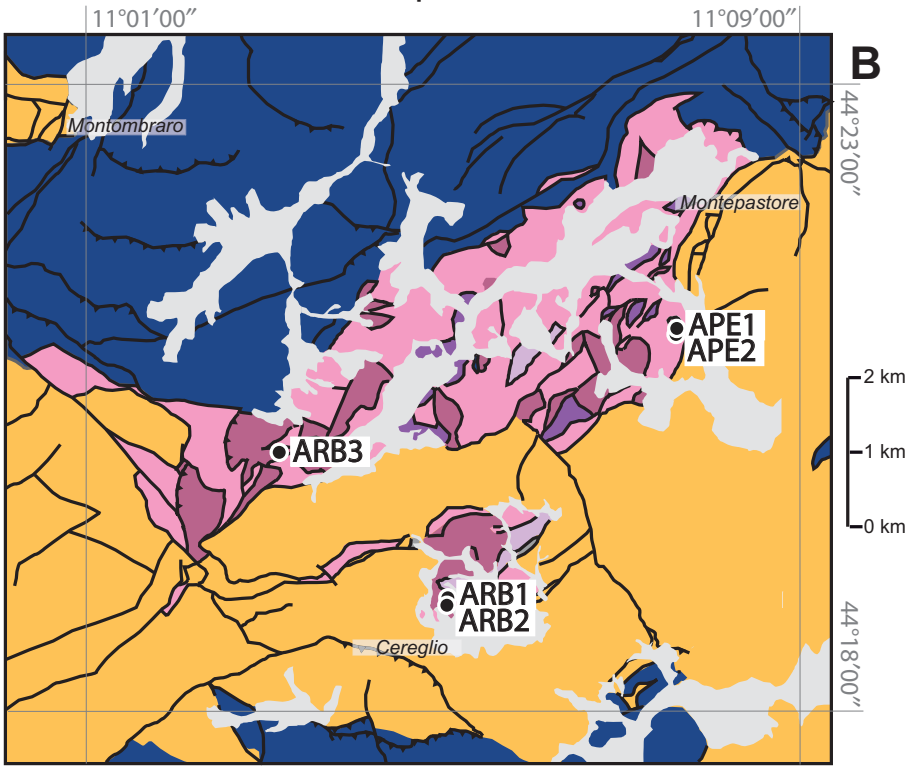

\section{C}

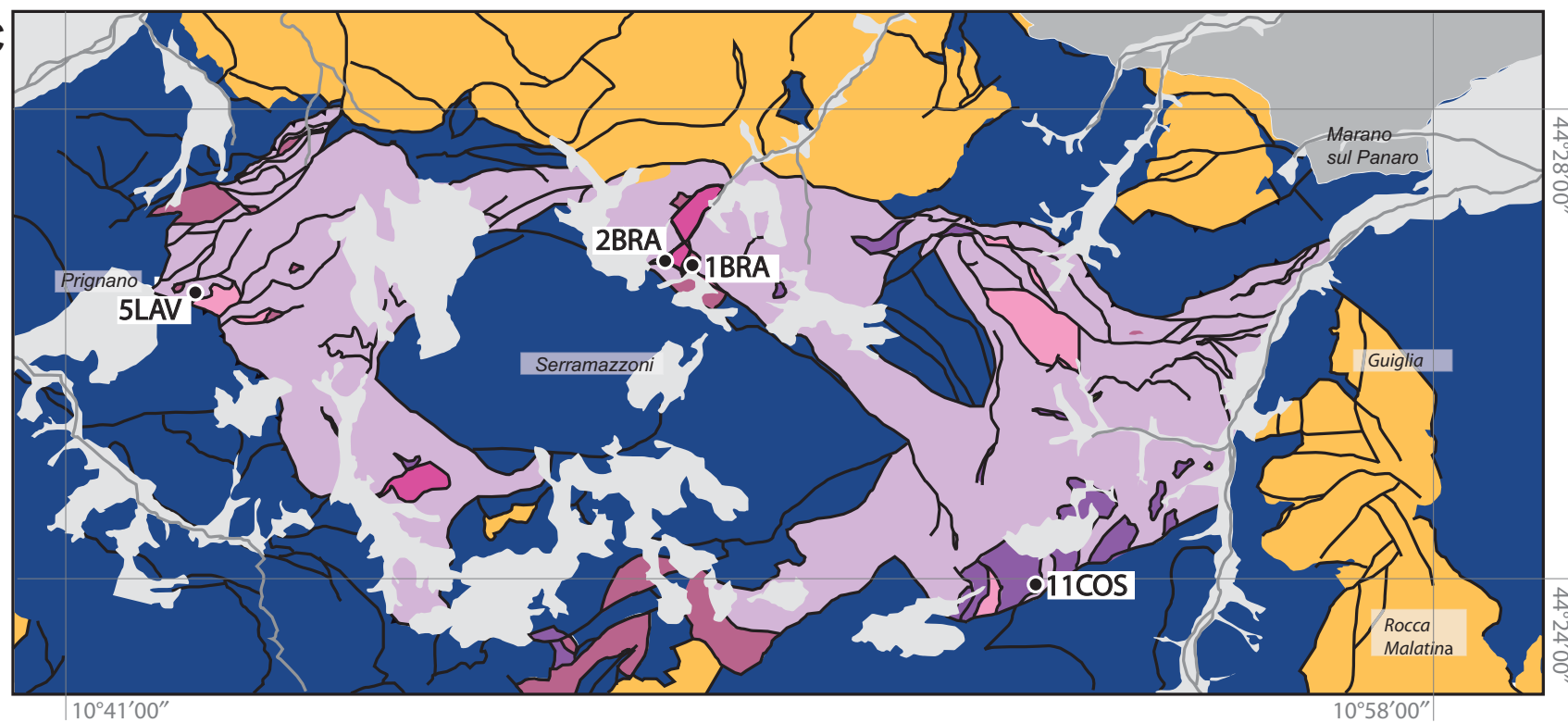

$\square$ Quaternary deposits Pliocene deposits

mélange components in MONTE STAFFOLA COSCOGNO MONTEPASTORE tectonic windows
ELM External Ligurian Units of Late Cretaceous-Paleocene age OPH, APA, AVV, SCB External Ligurian Units of Jurassic-Late Cretaceous age MPA Subligurian Units of early-middle Eocene age AVN, MSF1, MSF2 Subligurian Units of Late Cretaceous-early Eocene age ARB, PET, MSF3 Epi-Subligurian Units of Oligocene-early Miocene age

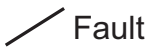

Thrust and overthrust Lithological boundary

Figure 3. Schematic geological maps of the studied outcrop areas of the three tectonic windows (red squares in Fig. 1) with sample locations (see Table 1). (A) Monte Staffola tectonic window (modified from the Geological Map of Italy, sheet no. 218 [Papani et al., 2002]). (B) Montepastore tectonic window (modified from the Geological Map of Italy, sheet no. 237 [Panini et al., 2002]). (C) Coscogno tectonic window (modified from the Geological Map of Italy, sheet nos. 219 [Gasperi and Preti, 2005] and 236 [Bettelli et al., $2002 \mathrm{~b}$ ]). 
Ligurian accretionary prism with its sedimentary cover (Bettelli et al., 2002b; Panini et al., 2002; Gasperi and Preti, 2005). The same interpretation has been proposed for the origin of the Sestola-Vidiciatico tectonic unit (Vannucchi et al., 2008) and the Subligurian Units (Remitti et al., 2011; Vannucchi et al., 2012).

Because in the three tectonic windows there are no blocks younger than the Aquitanian (early Miocene), the underthrusting must have occurred during or after that time. Moreover, the contact between the tectonic mélange and the surrounding Ligurian Units is locally sealed by the Epiligurian Units of Burdigalian (early Miocene) to late Miocene age. This occurrence suggests an early exhumation (i.e., during the early Miocene, 25-20 Ma) of the outcropping tectonic mélange (Bettelli et al., 2002b; Panini et al., 2002; Papani et al., 2002). This possible early Miocene exhumation age indicates that, after its underthrusting, the evolution of the tectonic mélange in the three tectonic windows followed a different path than the SestolaVidiciatico tectonic unit and Subligurian Units. All the above-mentioned units were underthrust together, but the Sestola-Vidiciatico tectonic unit and the Subligurian Units were exhumed less than 10 m.y. ago with the whole Apennine chain (Thomson et al., 2010) (Fig. 1).

Unfortunately, the reworking of the original Epiligurian stratigraphic contacts by recent high-angle normal faults (Fig. 3) makes the interpretation of an early exhumation of the tectonic mélange uncertain (see, for example, Cerrina Feroni et al., 2002b). To better constrain both the time of the underthrusting/exhumation of the tectonic mélange cropping out in the tectonic windows and the material pathways near the toe of the Ligurian prism during the Aquitanian, we performed apatite fission-track analyses on sandstone blocks from each of the three tectonic windows.

\section{APATITE FISSION-TRACK (AFT) DATA}

\section{Sampling and Method}

We collected 16 samples of representative sandstone blocks from the tectonic mélange cropping out in the three tectonic windows of the Emilia Apennines (Table 1; see also Fig. 3 for sample locations).

We choose to sample only blocks of wellknown stratigraphic age (Fig. 3) in order to have a strong external constraint when performing the AFT modeling (at the time corresponding to their stratigraphic ages, our rocks had to have been at surface temperatures). The stratigraphic age (Table 1) was defined by biostratigraphic analyses-using foraminifera and nannofossils-conducted during the CARG project (Geological CARtography project, aiming to produce geological mapping of Italy in its entirety at 1:50,000 scale; Bettelli et al., 2002b; Panini et al., 2002; Papani et al., 2002; Gasperi and Preti, 2005) for each sampled block (Fig. 3).

The AFT method is used to reconstruct the cooling history of the rocks as they moved toward the surface. This technique also provides information on their maximum burial depth. Fission tracks totally anneal at temperatures higher than $\sim 120{ }^{\circ} \mathrm{C}$ over geological time scales, but partial annealing occurs starting from $60{ }^{\circ} \mathrm{C}$. The $60-120{ }^{\circ} \mathrm{C}$ temperature range is called the partial annealing zone (PAZ) (Laslett et al., 1987). Usually, modeling procedures are applied to determine temperature-time paths compatible with AFT data (age plus track-length distribution; Gallagher, 1995; Ketcham, 2005; Ketcham et al., 2000). For the modeling we used the HeFTy program (Ketcham et al., 2007a, 2007b). This program defines the envelopes in a time-temperature space that contains all paths that yield statistically "good" and "acceptable" fits with the AFT data, respectively. In HeFTy, fission-track lengths normalized for track angle using c-axis projection (Ketcham et al., 2007a, 2009) and the annealing model of Ketcham et al. (2007b) were used. Only TINTs (tracks reached by etching through another track intercepting the polished apatite surface) were measured as recommended by Carlson et al. (1999).

In many instances, because of low fissiontrack density, only few (or no) tracks can be measured in each sample. Because a statistically consistent distribution is well determined by $\sim 100$ measurements, modeling procedures cannot always be applied. In these cases, when dealing with sedimentary rocks, it is critical to analyze the relationships between single-apatitegrain FT ages and their stratigraphic age. If all the single-grain ages are younger than the stratigraphic age of the sample, then all the grains have been annealed and the maximum temperature (Tmax) must have been equal to or greater than the temperature for complete annealing. The number of grain ages older than the stratigraphic age generally increases with decreasing Tmax. The proportion of single-grain ages older or younger than the stratigraphic age provides a qualitative means for estimating the paleoTmax. Radial plots give a visual description of the relationships between the grain ages and the stratigraphic age. The grain-age distributions of partially reset samples may be decomposed into different age components. Usually the grain-age distribution is subjected to a $\chi^{2}$ test (Galbraith, $1981)$ to detect whether a distribution is normally or overall dispersed. A $\mathrm{P}\left(\chi^{2}\right)$ probability less than $5 \%$ indicates a mixed discordant distribution, which is a distribution containing two or more grain-age components (Galbraith and Laslett, 1993). To decompose grain-age distributions, a binomial peak-fitting method (Brandon, 1996; Brandon et al., 1998; Galbraith, 1988) was used. This method is a statistical treatment that isolates the youngest group of concordant grain ages (minimum age; Galbraith and Laslett, 1993). For a sample that has been exposed to temperatures within the PAZ, the minimum age corresponds to the time when the sample cooled to a temperature outside the PAZ (Brandon et al., 1998). These minimum ages allow us to evaluate the time of exhumation, even for partially reset samples for which it is not possible to perform a modeling procedure due to few to no length measurements.

\section{Results}

The AFT data are shown in Table 1 and Figure 4 (radial plots) and modeling in Figure 5. We are showing the modeling only for those samples where we measured $>50$ tracks. We made an exception for only one sample from the Coscogno area (5LAV), where only 30 lengths were measured, in order to have some possible hints about its substantially different FT age with respect to the other samples (see Table 1 and Figs. 4 and 5). As stated in the previous paragraph, the stratigraphic age of the original rocks, strongly variable for each outcrop (from 75 to $23 \mathrm{Ma}$ ), is included in the modeling. The stratigraphic age of the sample is also reported in the sample radial plots, so that it can be compared with the ages of the single grains in order to get a qualitative evaluation of the degree of annealing of each sample. First we will discuss the results for each tectonic window.

\section{Montepastore Tectonic Window}

Five samples were analyzed from this tectonic window (APE1, APE2, ARB1, ARB2, ARB3; see Table 1 and Fig. 4; see also Fig. 3 and Table 1 for sample locations). Sample stratigraphic age ranges from the early Oligocene (34-28 Ma) (APE1, APE2) to the late Oligocene-early Miocene (ARB1, ARB2, ARB3). AFT ages vary from $26.7 \pm 3.9$ to $15.9 \pm 2.6 \mathrm{Ma}$; they are all younger than the stratigraphic age, implying that all the samples entered inside the PAZ and were partially to totally annealed. The number of measured FT lengths is small in all samples except in ARB2 (54 tracks; see modeling results in Fig. 5). For sample ARB2 modeling indicates maximum heating at temperatures of $\sim 120{ }^{\circ} \mathrm{C}$ or more and a subsequent cooling starting at ca. 25-20 Ma. As mentioned above, the sample stratigraphic age (Rupelian-Chattian) has been 
Remitti et al.

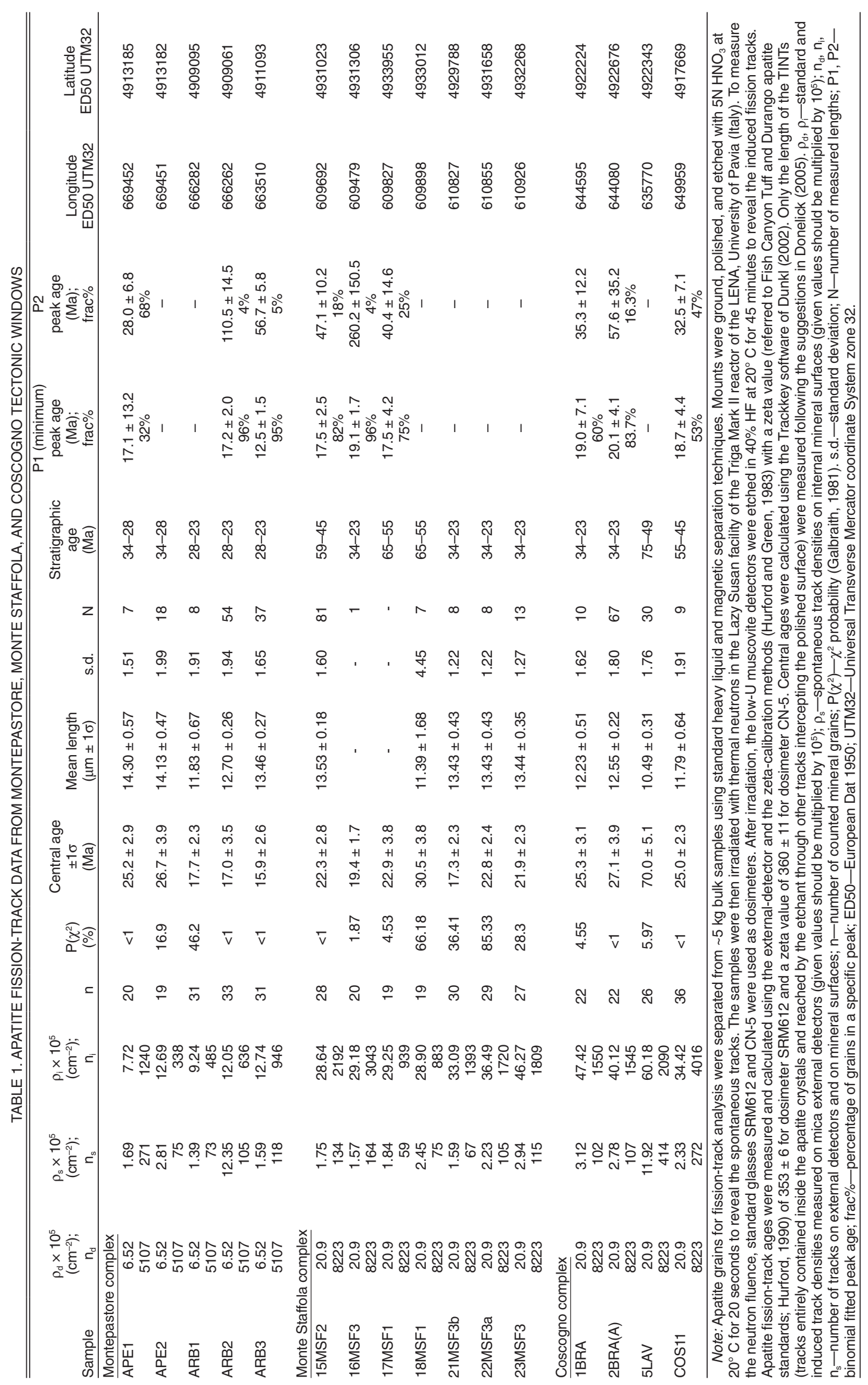


Montepastore
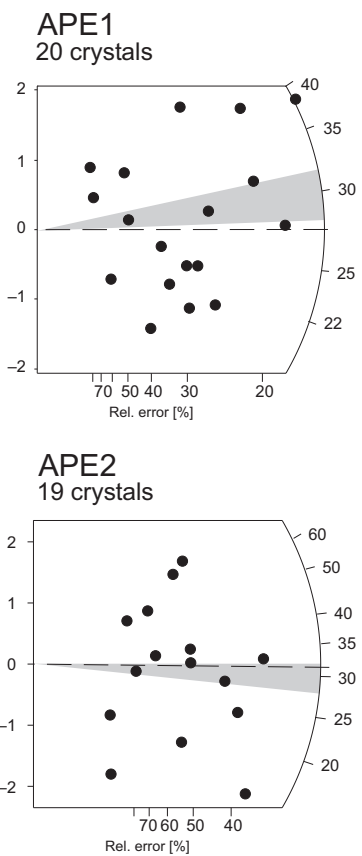

ARB2

33 crystals

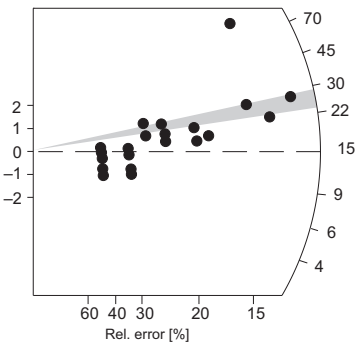

ARB1

31 crystals

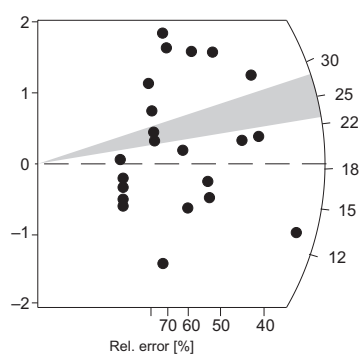

ARB3

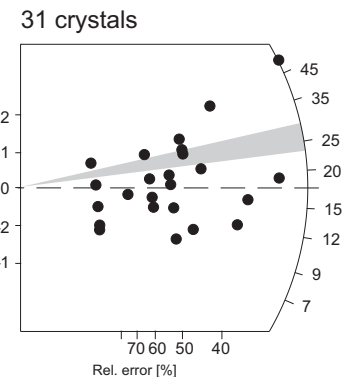

Monte Staffola

\section{Coscogno}
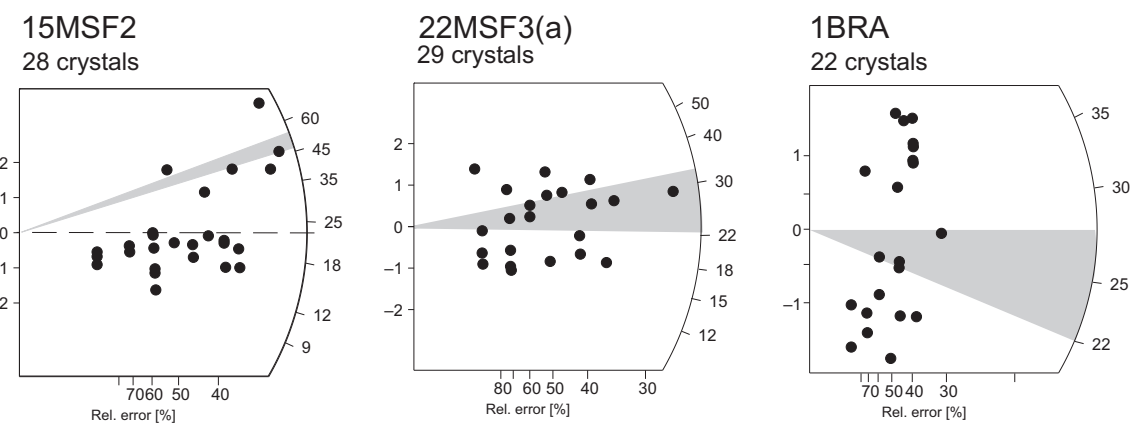

16MSF3

20 crystals

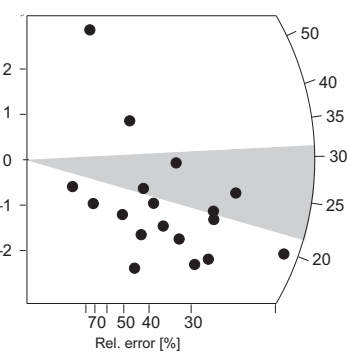

17MSF1

19 crystals
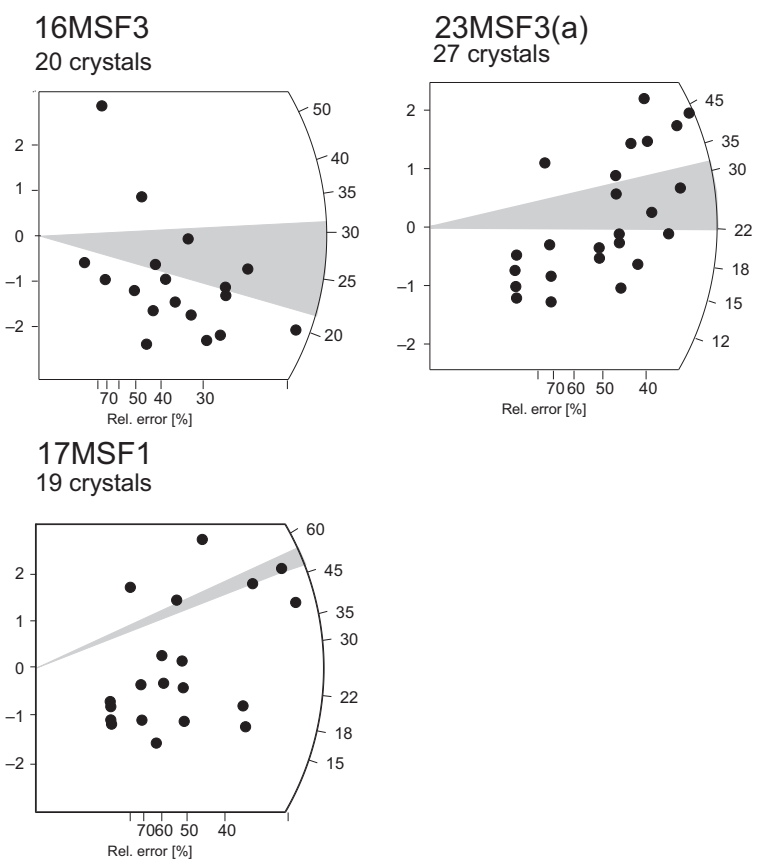

2BRA(2)

22 crystals

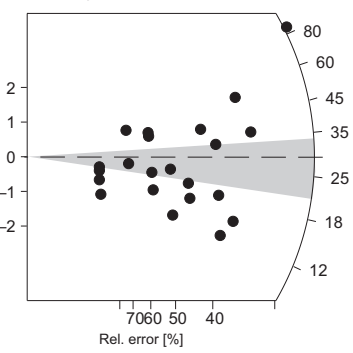

5LAV

26 crystals

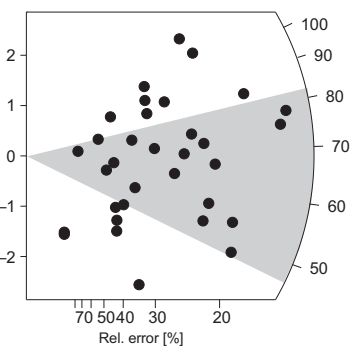

$\cos 11$

36 crystals

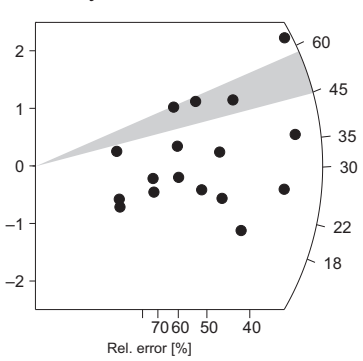

21MSF3b

30 crystals

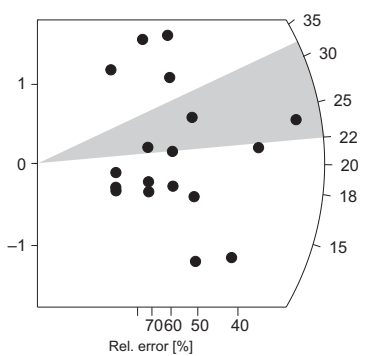

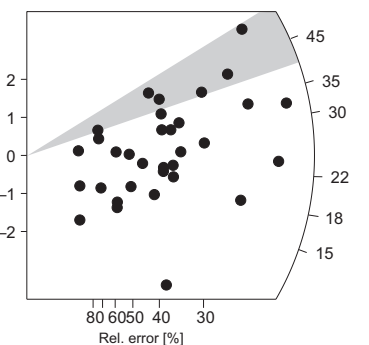

Figure 4. Radial plots of the samples showing single-grain ages. Each black dot represents a crystal. The age (in Ma) can be read as the intersection between a line passing from the origin through a dot and the radial scale on the right. Precision in age is reported on the $\mathrm{x}$-axis (relative error \%). The left-hand axis represents the height of the error bar for each grain age, which is of the same height for each grain. The error limits for each grain can be seen by projecting a line from the origin through the top and bottom if its error bar, so that a grain which is farther to the right will subtend a smaller error range on the radial axis and therefore be more precise than one further to the left. The shaded areas represent the sample depositional ages. 
Figure 5. For each modeled sample, timetemperature histories obtained with the HeFTy program (Ketcham et al., 2007a, 2007b) are shown. The program defines envelopes in a time-temperature space containing all paths that statistically yield "good" and "acceptable" fits with observed data, respectively. A model is considered "good" if all statistical parameters are greater than $\mathbf{0 . 5 0}$, while it is considered "acceptable" when statistical parameters are above 0.05 . On the left, the dark-gray regions bound the envelopes for statistically good fit, while the light-gray ones, the acceptable fit. Thick black lines represent the best fitting paths. On the right, the measured track-length distributions are shown as black curves. Fission-track lengths are normalized for track angle using c-axis projection (Ketcham et al., 2007a, 2009) and the annealing model of Ketcham et al. (2007b) was used. The $y$-axis reports the track length frequency that is normalized to 1.0. Model Age is the fission-track age predicted by HeFTy. Meas(Measured) Age is the pooled age from the measured data. Age GOF is the value of goodness-of-fit statistic for comparing the model to the measured. Model Length is the mean and standard deviation of the track length distribution predicted by HeFTy. Meas(ured) Length is the mean and standard deviation of the measured track length distribution. Length GOF is the value of the goodness-of-fit between the model and measured length distribution.

included as a constraint in the modeling and is represented in Figure 5 by the small box at surficial temperatures between 28 and $23 \mathrm{Ma}$. For ARB3, the radial plot (Fig. 4) shows that almost all grains are younger than the stratigraphic age indicating that this mélange block was close to total annealing (i.e., Tmax of $\sim 110-120{ }^{\circ} \mathrm{C}$ ) before being exhumed at a time approximate to its FT age (ca. $16 \pm 2 \mathrm{Ma}$ ). APE1 and APE2 samples have slightly older AFT ages of $25.2 \pm$ $2.9 \mathrm{Ma}$ and $26.7 \pm 3.9 \mathrm{Ma}$, respectively, and sample APE1 shows a $\mathrm{P}\left(\chi^{2}\right)$ value lower than 1. The radial plots of both samples APE1 and APE2 show that some grains are older than the Rupelian (33.9-28.1 Ma) stratigraphic age, thus we tentatively interpreted them as partially reset samples. We decomposed sample APE1 grainage distributions (Table 1) and obtained its minimum age which represents the time of the cooling below PAZ temperatures $\left(\sim 60{ }^{\circ} \mathrm{C}\right)$. It is not well-defined, due to the large error being $17.1 \pm 13.2 \mathrm{Ma}$.
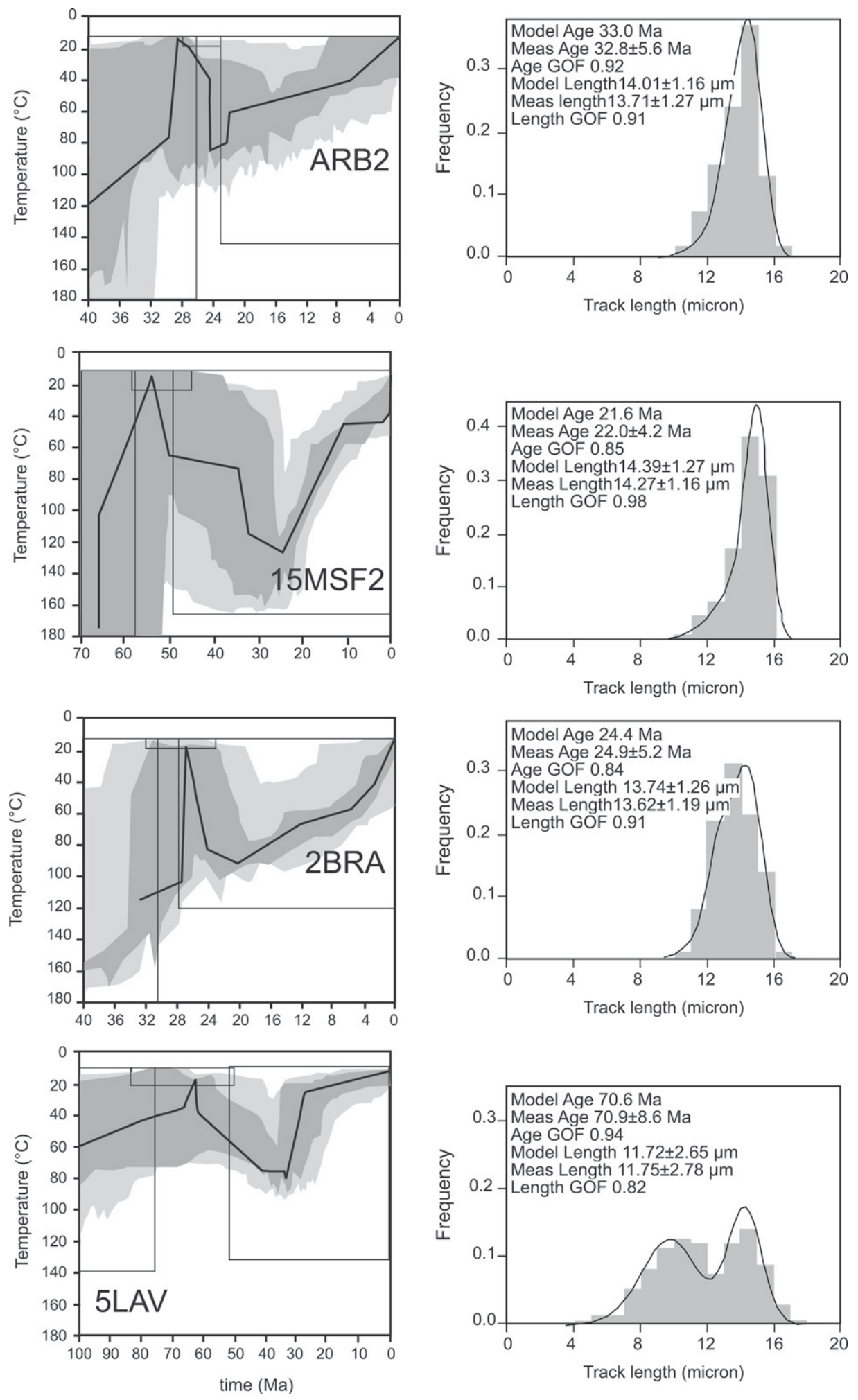

The AFT data from the Montepastore tectonic window point to a Tmax between $80{ }^{\circ} \mathrm{C}$ and $120^{\circ} \mathrm{C}$ or more with a subsequent exhumation starting at ca. 25-20 Ma, and a possible phase of rapid exhumation at ca. $17 \mathrm{Ma}$.

\section{Monte Staffola Tectonic Window}

From the Monte Staffola tectonic window we analyzed seven samples (15MSF2, 16MSF3, 17MSF1, 18MSF1, 21MSF3b, 22MSF3a, 23MSF3; see Table 1 and Fig. 4; see also Fig. 3 
and Table 1 for sample locations). The stratigraphic age of the samples ranges from the late Paleocene (ca. 65-55 Ma) to the late Oligocene (26-23 Ma). AFT ages range between $30.5 \pm$ $3.8 \mathrm{Ma}$ and $17.3 \pm 2.3 \mathrm{Ma}$. Also, for the samples from the Monte Staffola tectonic window, all of the AFT ages are younger than the stratigraphic age, implying that all the samples at least entered the PAZ.

Modeling was performed on sample 15MSF2 (AFT age of $22.3 \pm 2.8 \mathrm{Ma}$, number of measured lengths $=81$ ). The stratigraphic age of this sample is late(?) Paleocene-middle Eocene (see also Fig. 5). AFT modeling indicates that the Tmax were higher than $120^{\circ} \mathrm{C}$, with a total resetting of the FT system and a subsequent cooling that began between 25 and $22 \mathrm{Ma}$.

All the other samples, except 18MSF1, have AFT ages indistinguishable from that of sample 15MSF2 within a one-sigma error interval. Therefore, they are also interpreted as completely reset samples with a time of cooling below $\sim 100{ }^{\circ} \mathrm{C}$ that corresponds approximately to their AFT age. Sample 18MSF1, with its slightly older AFT age and a Paleocene stratigraphic age, is interpreted as having experienced a similar thermal history but probably being exposed to lower Tmax.

\section{Coscogno Tectonic Window}

Four samples were analyzed from the Coscogno tectonic window (1BRA, 2BRA, 5LAV, COS11; see Table 1 and Fig. 4; see also Fig. 3 and Table 1 for sample locations). The AFT ages of samples 1BRA, 2BRA and COS11 span a narrow range between $27.1 \pm 3.9$ Ma to $25.0 \pm$ $2.3 \mathrm{Ma}$. Sample 5LAV, collected near the boundary with the surrounding Ligurian Units, displays an AFT age of 70.0 $\pm 5.1 \mathrm{Ma}$, much older than the other three samples. In all samples, some of the AFT single-grain ages are younger than the stratigraphic age, implying that all the samples were heated to PAZ temperatures. Of the three youngest samples, we performed the modeling only on sample 2BRA (67 measured lengths). Modeling shows heating with a Tmax of $\sim 100{ }^{\circ} \mathrm{C}$ and a subsequent cooling starting at ca. 23-20 Ma. We interpret the other two younger samples (1BRA and COS11) as almost completely reset samples with their AFT ages $(25.3 \pm 3.1 \mathrm{Ma}$ and $25.0 \pm 2.3 \mathrm{Ma}$, respectively) roughly corresponding to their cooling below $\sim 100{ }^{\circ} \mathrm{C}$. The radial plot of sample COS 11 (Fig. 4) shows that the grain ages are younger than the stratigraphic age (Ypresian-Lutetian, ca. 55-40 Ma), which supports this interpretation. The samples 1BRA and 2BRA show low $\mathrm{P}\left(\chi^{2}\right)$ values and grain-age distributions with a certain number of grains older than their Rupelian (ca. 36-26 Ma) stratigraphic age. All three of the younger samples yielded decomposed minimum ages ranging between $20.1 \pm 4.1 \mathrm{Ma}$ and $18.7 \pm 4.4 \mathrm{Ma}$.

As mentioned above, we also present the modeling performed on sample 5LAV despite the few (30) measured lengths. This has been done in order to have some indication about how to interpret its "older" age: modeling shows Tmax at or below $80{ }^{\circ} \mathrm{C}$ and a subsequent cooling possibly starting later at ca. $10 \mathrm{Ma}$. These results, particularly the time of the last cooling, have to be taken with caution, because the modeling performed on a length distribution of only 30 length measurements can produce misleading results. Nevertheless, as it comes out from the modeling, the thermal history of sample 5LAV could be similar to that of the External Ligurian Units cropping out outside of the tectonic window (Thomson et al., 2010) and compatible with its peculiar mapped position close to the boundary of the tectonic window.

Apart from sample 5LAV, samples from the Coscogno tectonic window show a Tmax between $80{ }^{\circ} \mathrm{C}$ and $110{ }^{\circ} \mathrm{C}$, with cooling starting between 25 and $20 \mathrm{Ma}$.

\section{DISCUSSION}

\section{Thermal History of the Sampled Units}

All the analyzed samples (except 5LAV), irrespectively of their stratigraphic age and the tectonic window from which they were collected, share a common thermal history with a thermal overprint between $80{ }^{\circ} \mathrm{C}$ and $120{ }^{\circ} \mathrm{C}$ or more (Table 1; Figs. 4 and 5). If heating was mainly due to burial, assuming a geothermal gradient for the outer side of the Northern Apennines of $20^{\circ} \mathrm{C} / \mathrm{km}$ (Zattin et al., 2002), then all samples were buried at depths ranging from 3 to $5 \mathrm{~km}$. The AFT data also indicate that these rocks began to cool down at ca. 25-20 Ma. As the maximum sedimentary load that we can infer in the Aquitanian time (ca. 23-20 Ma)-i.e., the maximum thickness of the pre-Burdigalian Epiligurian Successionis less than $1 \mathrm{~km}$, a sedimentary burial alone cannot explain the data. This interpretation is strengthened by a regional thermochronological study which shows that the Ligurian Units adjacent to the tectonic windows, and underlying the whole Epiligurian Succession, reached a Tmax $<70{ }^{\circ} \mathrm{C}$ before being exhumed in the last 10 m.y. (Thomson et al., 2010). This temperature is much cooler than what we found in the tectonic windows, therefore a component of tectonic overburden must be inferred.

At present, the thickness of the Ligurian Units in the study area is $>2 \mathrm{~km}$ (from boreholes; see http://unmig.sviluppoeconomico.gov.it/videpi /en/) implying that if the material exposed in the three tectonic windows was underthrust beneath the Ligurian prism and its sedimentary cover (i.e., the Epiligurian Succession), it could have reached a maximum depth between 3 and $5 \mathrm{~km}$, compatible with the data. This result agrees with an Aquitanian underthrusting of the sampled material and with the interpretation that the material cropping out in the three tectonic windows is a lateral equivalent of the SestolaVidiciatico tectonic unit and the Subligurian Units, i.e., the material forming the plate boundary shear zone between the overlying Ligurian Units and the underlying Tuscan and Umbrian successions.

A 25-20 Ma age of cooling and exhumation below $80{ }^{\circ} \mathrm{C}$ is recorded in all sampled blocks, including those with a Chattian (28$23 \mathrm{Ma}$, sample ARB2) stratigraphic age. The youngest blocks in the mélange are Aquitanian (23-20 Ma), but they are unsuitable for AFT sampling because they have a marly composition. Nonetheless, in the mélange the Aquitanian blocks are tied together with the Chattian blocks and must share the same evolution. The implication is that the heating and successive cooling of the tectonic mélange occurred soon after the deposition of its components ( $<3$ m.y.) (see location 1 in Fig. 6). Today the sampled tectonic mélange is cropping out at a very short distance $(\sim 10-20 \mathrm{~km})$ from the inferred Aquitanian deformation front implying that both heating/burial and cooling/exhumation resulted from rapid tectonic processes involving the frontal part of the upper plate. Based on our reconstruction, the closure of the complete heating/burial-cooling/exhumation cycle of the tectonic mélange is possible considering an Aquitanian underthrusting rate for the Adriatic foredeep of $>\sim 7 \mathrm{~mm} / \mathrm{yr}$.

Cooling could have been the result of the development of either thrust faults or normal faults in the upper plate. A compression-induced exhumation in the frontal prism might have been accommodated either by out-of-sequence thrusts or by the progressive growth of an antiformal stack linked with enhanced seafloor erosion (Fig. 6B). We do not favor this hypothesis because the detailed geological mapping of the study area does not show doubling of the Ligurian Units and/or pre-Aquitanian Epiligurian Succession as would be expected for a thrust that cuts through the prism (as for instance at Nankai; cf. Strasser et al., 2009). An alternative hypothesis for the reduction of the prism thickness, the exhumation of the studied units, and their exit from the PAZ (Fig. 6C), is represented by normal faults cutting the frontal part of the forearc. Widespread syn-lithification extension has been recorded in the frontal part of the 
AQUITANIAN (23-20 Ma)

\section{Epiligurian Succession}
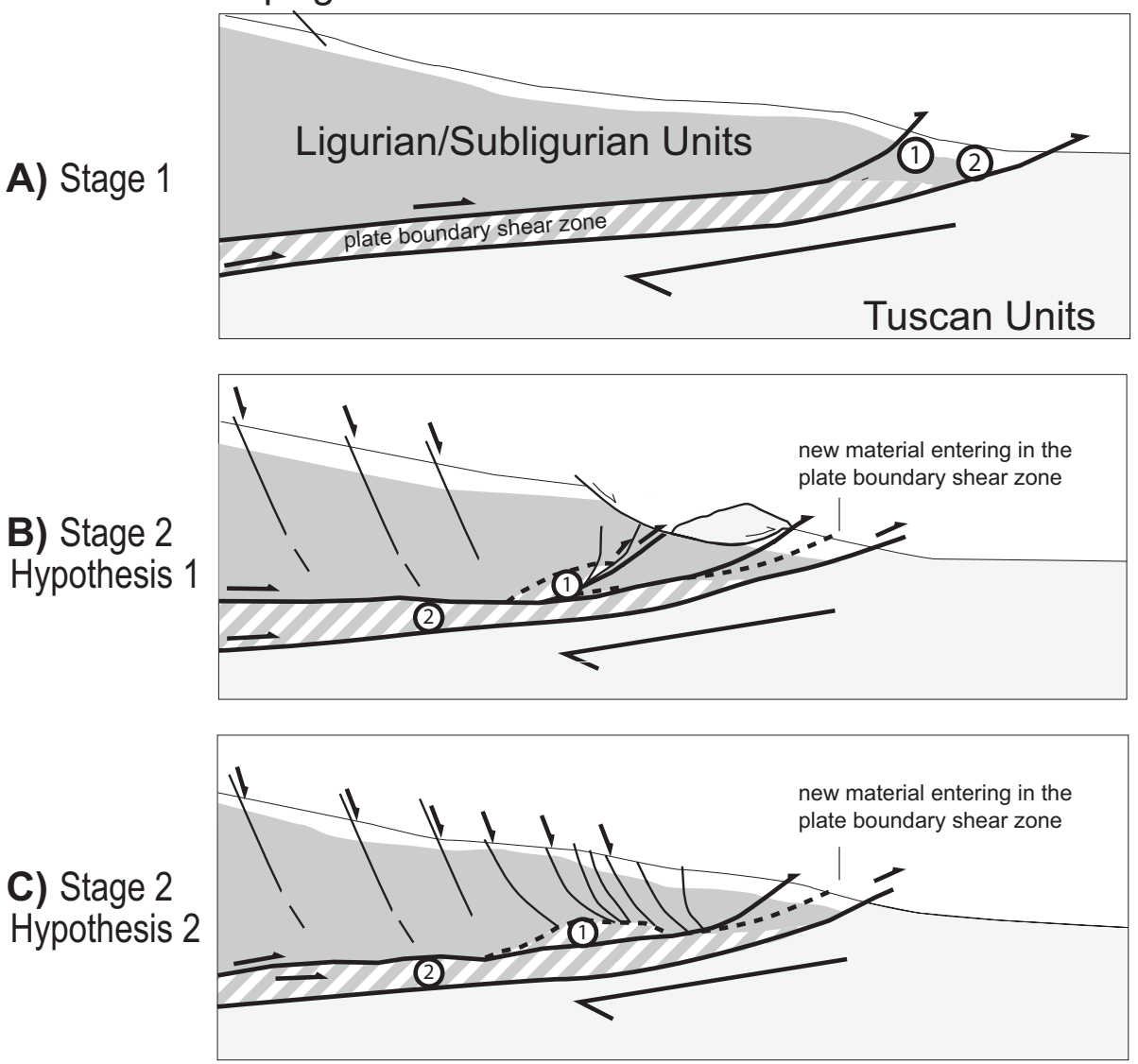

Figure 6. Conceptual model of the evolution of the frontal part of the subduction zone of the Northern Apennines in the Aquitanian (early Miocene, 23-20 Ma). Location 1 represents the path followed by the sampled material which is today cropping out in the three studied tectonic windows (Montepastore, Monte Staffola, and Coscogno tectonic windows); location 2 represents the path followed by the material which is today cropping out $70 \mathrm{~km}$ southwestward of the sampled material. (A) Stage 1. Deposition of slope sediments of Aquitanian age and underthrusting of the toe of the prism (tectonic erosion) which entered in the plate boundary shear zone. (B) Stage 2, hypothesis 1. Deactivation of the former roof décollement. A portion of the plate boundary shear zone (location 1) cools to $<80^{\circ} \mathrm{C}$ because of the activation of an out-of-sequence thrust coupled with enhanced erosion. The plate boundary shear zone is still active because a new roof décollement allows the other portion (location 2) to keep on moving. (C) Stage 2, hypothesis 2. Deactivation of the former roof décollement. A portion of the plate boundary shear zone (location 1) cools to $<80^{\circ} \mathrm{C}$ because of the thinning of the upper plate through normal faulting. The plate boundary shear zone is still active because a new roof décollement allows the other portion (location 2) to keep on moving.

Sestola-Vidiciatico tectonic unit (Vannucchi et al., 2008; Remitti et al., 2012), which is a lateral equivalent of the sampled mélange. In general, this "extensional" hypothesis is compatible with the structural setting of the frontal part of erosive margins as it has been imaged in many modern examples (see von Huene et al., 2004; Ito et al., 2011). Exhumation was also a main effect triggered by the massive mass-wasting event that completely disrupted the sedimen- tary cover in the frontal part of the prism during the Aquitanian as documented by Remitti et al. (2011) and Codegone et al. (2012).

\section{Comparison with the Thermal History of the Sestola-Vidiciatico Tectonic Unit}

The AFT analysis coupled with the existing detailed geological data allows us to trace the pathways followed by the sampled units (Fig. 6).
These units entered the plate boundary shear zone in the Aquitanian (ca. 23-20 Ma), as suggested by the age of the younger blocks in the mélange. We can now compare their trajectory to the path followed by the Sestola-Vidiciatico tectonic unit, which was underthrust in the same period (Aquitanian) and is now cropping out near the Northern Apennines water divide ( $70 \mathrm{~km}$ to the southwest of the three tectonic windows; see Fig. 1).

These units shared the first part of their trajectory, being underthrust to a (map) distance of $\sim 10-20 \mathrm{~km}$ from the inferred prism front where they reached a temperature of $\sim 80-120^{\circ} \mathrm{C}$, i.e., a depth of $\sim 3-5 \mathrm{~km}$. There, the portion of the plate boundary shear zone presently cropping out in the three tectonic windows started to cool down. The beginning of exhumation is now fixed at ca. 25-20 Ma. The rest of the material kept on moving along the plate boundary, reaching a depth at which the temperature exceeded $120^{\circ} \mathrm{C}$. This latter part was then exhumed starting at $<10 \mathrm{Ma}$ (AFT and $[\mathrm{U}-\mathrm{Th}] / \mathrm{He}$ data in Thomson et al., 2010). During the exhumation stage at 25-20 Ma, the plate boundary shear zone was active. In fact, the age of the underthrusting Adria sedimentary cover suggests that the basal décollement of the shear zone remained active until the middle Miocene. Moreover, the stratigraphic age of the slope sediment blocks inside the plate boundary shear zone becomes progressively younger toward the front, where blocks of middle Miocene (ca. $15 \mathrm{Ma}$ ) age are present. This implies that at that time the plate boundary shear zone was still incorporating new material at the front, through a process of frontal tectonic erosion and through the activity of a roof décollement of the shear zone (sensu Vannucchi et al., 2008).

The different fates of these two exposed portions of the plate boundary shear zone imply that there was an episode of underplating and exhumation during the period of activity of the shear zone itself. Underplating implies that locally the roof décollement of the plate boundary shear zone was deactivated, and the differential displacement between the upper plate and the subducting plate migrated toward a lower, newly formed fault (a new roof décollement) within the plate boundary shear zone (Fig. 6).

\section{CONCLUSIONS}

In the Northern Apennines, the early Miocene subduction of the continental Adria plate under the frontal part of the European plate occurred with a tectonic process of frontal subduction erosion (Vannucchi et al., 2008). The Apennine plate interface is preserved and is formed by a $\sim 500 \mathrm{~m}$ thick shear zone accommodating the relative displacement between the two plates. 
We analyzed the plate boundary shear zone material that crops out in three tectonic windows located $\sim 15 \mathrm{~km}$ from the inferred position of the original deformation front. This material was sampled for apatite fission-track (AFT) analysis. The results were compared with those obtained from the material of the plate boundary shear zone that underthrust at the same time of the sampled material, but that is now cropping out $70 \mathrm{~km}$ to the southwest as the SestolaVidiciatico tectonic unit. The new AFT data combined with geological and stratigraphic constraints, including the regional thermochronological study by Thomson et al. (2010), suggest the following:

(1) The material cropping out in the three tectonic windows and the Sestola-Vidiciatico tectonic unit were transported using different pathways in the frontal part of the plate boundary shear zone. While the Sestola-Vidiciatico tectonic unit was incorporated within the plate interface and underthrust toward the deeper levels of the forearc, a portion of it was underplated close to the front and soon started to be exhumed at ca. 25-20 Ma inside the frontal prism.

(2) The deactivation of at least part of the roof fault is the mechanism controlling the different pathways inside the plate boundary shear zone. The deactivation must have been followed by the generation of a new fault cutting inside the shear zone which could accommodate further the observed displacement.

(3) Although frontal erosion was still active, allowing material transfer from the tip of the upper plate to the plate interface, episodic underplating of underthrust material occurred.

(4) The frontal part of the upper plate underwent a strong phase of deformation, probably extensional, during the activity of the plate boundary shear zone.

These data give a new insight into the mechanics of the frontal prism in subduction zones. In particular here we demonstrate that the frontal prism can deform internally to a point that it can allow exhumation of material even in the shallowest portions of the system. Moreover, multiple faults with different kinematic behavior can cut through a range of possible material, for instance, upper plate material or mélange material. These faults can potentially lead to different seismic behavior of the frontal prism through time. In fact, different incremental processes of lithification, or fluid pressure changes, coupled with fault kinematics, strongly influence fault properties. We now know, for example, that in certain situations, earthquake rupture can propagate to the frontal prism (Kodaira et al., 2012) with a great tsunamogenic potential. The sampled mélange records a wide spectrum of processes that not only help constrain the paleotectonic setting of the Miocene Northern Apennines, but also can have important implications for the study of the seismic behavior of segments of plate boundaries in subduction zones.

\section{ACKNOWLEDGMENTS}

The authors would like to thank the editor Christian Koeberl, the associate editor Enrico Tavarnelli, and Andrea Festa and an anonymous reviewer for the helpful suggestions that greatly improved the manuscript. The authors also thank Filippo Panini for fruitful discussions. This research was financially supported by Ministero dell'Istruzione, dell'Università e della Ricerca (MIUR) research grants PRIN 2008 and PRIN 2010/2011 to G. Bettelli.

\section{REFERENCES CITED}

Argnani, A., 2002, The northern Apennines and the kinematics of Africa-Europe convergence: Bollettino della Società Geologica Italiana: Volume Speciale, v. 1, p. 47-60.

Bettelli, G., and De Nardo, M.T., 2001, Geological outlines of the Emilia Apennines (Italy): An introduction to the rock units cropping out in the areas of landslides reactivated in the 1994-1999 period: Quaderni di Geologia Applicata, v. 8, no. 1, p. 1-26.

Bettelli, G., and Panini, F., 1989, I mélanges dell Appennino settentrionale dal T. Tresinaro al T. Sillaro: Memorie della Societa Geologica Italiana, v. 39, p. 187-214.

Bettelli, G., and Vannucchi, P., 2003, Structural style of the offscraped Ligurian oceanic sequences of the Northern Apennines: New hypothesis concerning the development of mélange block-in-matrix fabric: Journal of Structural Geology, v. 25, p. 371-388, doi:10.1016 /S0191-8141(02)00026-3.

Bettelli, G., Bonazzi, U., and Panini, F., 1989a, Schema introduttivo alla geologia delle Liguridi dell'Appennino modenese e delle aree limitrofe: Memorie della Società Geologica Italiana, v. 39, p. 91-126.

Bettelli, G., Bonazzi, U., Fazzini, P., and Panini, F., 1989b, Schema introduttivo alla geologia delle Epiliguridi dell'Appennino modenese e delle aree limitrofe: Memorie della Società Geologica Italiana, v. 39, p. 215-244.

Bettelli, G., Boccaletti, M., Cibin, U., Panini, F., Poccianti, C., Rosselli, S., and Sani, F., 2002a, Carta Geologica d'Italia alla scala 1:50.000, Foglio 252 "Barberino del Mugello": Firenze, Servizio Geologico d'Italia-Regione Emilia Romagna, 1 sheet, 130 p. text.

Bettelli, G., Panini, F., and Pizziolo, M., 2002b, Carta Geologica d'Italia alla scala 1:50.000, Foglio 236 "Pavullo nel Frignano": Firenze, Servizio Geologico d'ItaliaRegione Emilia Romagna, 1 sheet, 165 p. text.

Brandon, M., 1996, Probability density plot for fission-track grain-age samples: Radiation Measurements, v. 26, p. 663-676, doi:10.1016/S1350-4487(97)82880-6.

Brandon, M.T., Roden-Tice, M.K., and Garver, J.I., 1998 , Late Cenozoic exhumation of the Cascadia accretionary wedge in the Olympic Mountains, northwest Washington State: Geological Society of America Bulletin, v. 110, p. 985-1009, doi:10.1130/0016-7606(1998)110 $<0985$ :LCEOTC >2.3.CO;2.

Capitani, M., 1997, Analisi macrostrutturale del sistema di deformazioni trasversali della Val Lavino (Appennino settentrionale, Italia): Atti Ticinesi di Scienze della Terra, v. 39, p. 65-77.

Carlson, W.D., Donelick, R.A., and Ketcham, R.A., 1999, Variability of apatite fission-track annealing kinetics I: Experimental results: The American Mineralogist, v. 84, p. $1213-1223$.

Cerrina Feroni, A., Ottria, G., and Vescovi, .P., 2002a, Carta Geologica d'Italia alla scala 1:50.000, Foglio 217 Neviano degli Arduini: Firenze, Servizio Geologico d'Italia-Regione Emilia Romagna, 1 sheet, 112 p. text. Cerrina Feroni, A., Ottria, G., Martinelli, P., and Martelli, L., 2002b, Structural Geological Map of the Emilia-
Romagna Apennines: Firenze, SELCA (Società Elaborazioni Cartografiche), scale 1:250,000.

Clift, P., and Vannucchi, P., 2004, Controls on tectonic accretion versus erosion in subduction zones: Implications for the origin and recycling of the continental crust: Reviews of Geophysics, v. 42, RG2001, doi: 10.1029/2003RG000127.

Codegone, G., Festa, A., Dilek, Y., and Pini, G.A., 2012 , Small-scale polygenetic mélanges in the Ligurian accretionary complex, Northern Apennines, Italy, and the role of shale diapirism in superposed mélange evolution in orogenic belts: Tectonophysics, v. 568-569, p. 170-184, doi:10.1016/j.tecto.2012.02.003.

Coward, M., and Dietrich, D., 1989, Alpine tectonics: An overview, in Coward, M.P., Dietrich, D., and Park, R.G., eds., Alpine Tectonics: Geological Society of London Special Publication 45, p. 1-29.

Donelick, R.A., 2005, Apatite fission-track analysis: Reviews in Mineralogy and Geochemistry, v. 58, p. 4994, doi:10.2138/rmg.2005.58.3.

Dunkl, I., 2002, Trackkey: A Windows program for calculation and graphical presentation of fission-track data: Computers \& Geosciences, v. 28, p. 3-12, doi:10.1016 /S0098-3004(01)00024-3.

Elter, P., Grasso, M., Parotto, M., and Vezzani, L., 2003 , Structural setting of the Apennine-Maghrebian thrust belt: Episodes, v. 26, p. 205-211.

Faccenna, C., Becker, T.W., Lucente, F.P., Jolivet, L., and Rossetti, F., 2001, History of subduction and back-arc extension in the Central Mediterranean: Geophysical Journal International, v. 145 , p. 809-820, doi: 10.1046/j.0956-540x.2001.01435.x.

Fagereng, A., 2011, Geology of the seismogenic subduction thrust interface, in Fagereng, A., Toy, V.G., and Rowland, J., eds., Geology of the Earthquake Source: A Volume in Honour of Rick Sibson: Geological Society of London Special Publication 359, p. 55-76.

Festa, A., Pini, G.A., Dilek, Y., and Codegone, G., 2010a, Mélanges and mélange-forming processes: A historical overview and new concepts: International Geology Review, v. 52, p. 1040-1105, doi:10.1080/00206810903557704.

Festa, A., Pini, G.A., Dilek, Y., Codegone, G., Vezzani, L., Ghisetti, F., Lucente, C.C., and Ogata, K., 2010b, PeriAdriatic mélanges and their evolution in the Tethyan realm: International Geology Review, v. 52, p. 369403, doi:10.1080/00206810902949886.

Galbraith, R.F., 1981, On statistical models for fission track counts: Mathematical Geology, v. 13, p. 471-478, doi: 10.1007/BF01034498

Galbraith, R.F., 1988, Graphical display of estimates having differing standard errors: Technometrics, v. 30, p. 271281, doi:10.1080/00401706.1988.10488400.

Galbraith, R.F., and Laslett, G.M., 1993, Statistical models for mixed fission track ages: Nuclear Tracks and Radiation Measurements, v. 21, p. 459-470, doi:10.1016 /1359-0189(93)90185-C.

Gallagher, K., 1995, Evolving temperature histories from apatite fission-track data: Earth and Planetary Science Letters, v. 136, p. 421-435, doi:10.1016/0012-821X (95)00197-K.

Gasperi, G., and Preti, D., 2005, Carta Geologica d'Italia alla scala 1:50.000, Foglio 219 "Sassuolo": Firenze, Servizio Geologico d'Italia-Regione Emilia Romagna, 1 sheet, 196 p. text.

Hurford, A.J., 1990, Standardization of fission track dating calibration: Recommendation by the Fission Track Working Group of the I.U.G.S. Subcommission on Geochronology: Chemical Geology: Isotope Geoscience Section, v. 80, p. 171-178, doi:10.1016 /0168-9622(90)90025-8

Hurford, A.J., and Green, P.F., 1983, The zeta age calibration of fission-track dating: Chemical Geology, v. 41, p. 285-317, doi:10.1016/S0009-2541(83)80026-6.

Ito, Y., Tsuji, T., Osada, Y., Kido, M., Inazu, D., Hayashi, Y. Tsushima, H., Hino, R., and Fujimoto, H., 2011, Frontal wedge deformation near the source region of the 2011 Tohoku-Oki earthquake: Geophysical Research Letters, v. 38, L00G05, doi:10.1029/2011GL048355.

Ketcham, R.A., 2005, Forward and inverse modeling of low-temperature thermochronometry data: Reviews in Mineralogy and Geochemistry, v. 58, p. 275-314, doi: 10.2138/rmg.2005.58.11. 


\section{Remitti et al.}

Ketcham, R.A., Donelick, R.A., and Donelick, M.B., 2000, AFTSolve: A program for multi-kinetic modeling of apatite fission-track data: Geological Materials Research, v. 2, no. 1, p. 1-32.

Ketcham, R.A., Carter, A.C., Donelick, R.A., Barbarand, J., and Hurford, A.J., 2007a, Improved measurement of fission-track annealing in apatite using c-axis projection: The American Mineralogist, v. 92, p. 789-798, doi:10.2138/am.2007.2280.

Ketcham, R.A., Carter, A.C., Donelick, R.A., Barbarand, J., and Hurford, A.J., 2007b, Improved modeling of fission-track annealing in apatite: The American Mineralogist, v. 92, p. 799-810, doi:10.2138/am.2007.2281.

Ketcham, R.A., Donelick, R.A., Balestrieri, M.L., and Zattin, M., 2009, Reproducibility of apatite fissiontrack length data and thermal history reconstruction: Earth and Planetary Science Letters, v. 284, p. 504 515, doi:10.1016/j.eps1.2009.05.015.

Kodaira, S., No, T., Nakamura, Y., Fujiwara, T., Kaiho, Y Miura, S., Takahashi, N., Kaneda, Y., and Taira, A., 2012, Coseismic fault rupture at the trench axis during the 2011 Tohoku-oki earthquake: Nature Geoscience, v. 5, p. 646-650, doi:10.1038/ngeo 1547.

Konstantinovskaya, E., and Malavieille, J., 2011, Thrust wedges with décollement levels and syntectonic erosion: A view from analogue models: Tectonophysics, v. 502, p. 336-350, doi:10.1016/j.tecto.2011.01.020

Laslett, G.M., Green, P.F., Duddy, I.R., and Gleadow, A.J.W., 1987, Thermal annealing of fission track in apatite: 2. A quantitative analysis: Chemical Geology, v. 65, p. 1-13, doi:10.1016/0168-9622(87)90057-1.

Lucente, C.C., and Pini, G.A., 2008, Basin-wide masswasting complexes as markers of the Oligo-Miocene foredeep-accretionary wedge evolution in the Northern Apennines, Italy: Basin Research, v. 20, p. 49-71, doi:10.1111/j.1365-2117.2007.00344.x.

Malusà, M.G., and Balestrieri, M.L., 2012, Burial and exhumation across the Alps-Apennines junction zone constrained by fission-track analysis on modern river sands: Terra Nova, v. 24, p. 221-226, doi:10.1111/j.1365 $-3121.2011 .01057 . x$.

Marroni, M., 1994, Deformation path of the Internal Ligurid Units (Northern Apennines, Italy): Record of shallowlevel underplating in the Alpine accretionary wedge: Memorie della Società Geologica Italiana, v. 48, p. 179-194.

Marroni, M., and Pandolfi, L., 1996, The deformation history of an accreted ophiolite sequence: The interna Liguride units (northern Apennines, Italy): Geodinamica Acta, v. 9, p. 13-29.

Marroni, M., Molli, G., Montanini, A., Ottria, G., Pandolfi, L., and Tribuzio, R., 2002, The external Ligurian Units of the Northern Apennines, Italy: From rifting to convergence of a fossil ocean-continent transition zone: Ofioliti, v. 27, p. 119-132.
Marroni, M., Meneghini, F., and Pandolfi, L., 2010, Anatomy of the Ligure-Piemontese subduction system: Evidence from Late Cretaceous-middle Eocene convergent margin deposits in the Northern Apennines, Italy: International Geology Review, v. 52, p. 1-33, doi: $10.1080 / 00206810903545493$.

Molli, G., 2008, Northern Apennines Corsica orogenic system: An updated overview, in Siegesmund, S., Fügenschuh, B., and Froitzheim, N., eds., Tectonic Aspects of the Alpine-Dinaride-Carpathian System: Geological Society of London Special Publication 298, p. 413442, doi:10.1144/SP298.19.

Molli, G., and Malavieille, J., 2011, Orogenic processes and the Corsica/Apennines geodynamic evolution: Insights from Taiwan: International Journal of Earth Sciences: Geologische Rundschau, v. 100, p. 1207-1224, doi:10.1007/s00531-010-0598-y.

Panini, F., Bettelli, G., and Pizziolo, M., 2002, Carta Geologica d'Italia alla scala 1:50.000, Foglio 237 "Sasso Marconi": Firenze, Servizio Geologico d'Italia-Regione Emilia Romagna, 1 sheet, 176 p. text.

Papani, G., De Nardo, M.T., Bettelli, G., Rio, D., Tellini, C., and Vernia, L., 2002, Carta Geologica d'Italia alla scala 1:50.000, Foglio 218 “Castelnovo Ne' Monti”: Firenze, Servizio Geologico d'Italia-Regione Emilia Romagna, 1 sheet, 140 p. text.

Plesi, G., 2002. Note illustrative della Carta Geologica d'Italia alla scala 1:50.000, Foglio 235 "Pievepelago": Firenze, Servizio Geologico d'Italia-Regione Emilia Romagna, 1 sheet, 138 p. text.

Principi, G., and Treves, B., 1984, Il sistema Corso-Appenninico come prisma di accrezione: Riflessi sul problema generale del limite Alpi-Appennini: Memorie della Società Geologica Italiana, v. 28, p. 549-576.

Remitti, F., Bettelli, G., and Vannucchi, P., 2007, Internal structure and tectonic evolution of an underthrust tectonic mélange: The Sestola-Vidiciatico tectonic unit of the northern Apennines, Italy: Geodinamica Acta, v. 20, p. 37-51, doi:10.3166/ga.20.37-51.

Remitti, F., Vannucchi, P., Bettelli, G., Fantoni, L., Panini, F., and Vescovi, P., 2011, Tectonic and sedimentary evolution of the frontal part of an ancient subduction complex at the transition from accretion to erosion: The case of the Ligurian wedge of the northern Apennines, Italy: Geological Society of America Bulletin, v. 123, p. 51-70, doi:10.1130/B30065.1.

Remitti, F., Bettelli, G., Panini, F., Carlini, M., and Vannucchi, P., 2012, Deformation, fluid flow, and mass transfer in the forearc of convergent margins: A two-day field trip in an ancient and exhumed erosive convergent margin in the Northern Apennines, in Vannucchi, P., and Fisher, D., eds., Deformation, Fluid Flow, and Mass Transfer in the Forearc of Convergent Margins: Field Guides to the Northern Apennines in Emilia and in the Apuan Alps (Italy): Geological Society of America Field Guide, v. 28, p. 1-34, doi:10.1130 /2012.0028(01).

Ricci Lucchi, F. 1990, Turbidites in foreland and on-thrust basins of the northern Apennines: Palaeogeography, Palaeoclimatology, Palaeoecology, v. 77, p. 51-66, doi:10.1016/0031-0182(90)90098-R.

Strasser, M., Moore, G.F., Kimura, G., Kitamura, Y., Kopf A.J., Lallemant, S., Park, J.-O., Screaton, E.J., Su, X., Underwood, M.B., and Zhao, X., 2009, Origin and evolution of a splay fault in the Nankai accretionary wedge: Nature Geoscience, v. 2, p. 648-652, doi:10.1038/ngeo609.

Thomson, S.N., Brandon, M.T., Reiners, P.W., Zattin, M. Isaacson, P.J., and Balestrieri, M.L., 2010, Thermochronologic evidence for orogen-parallel variability in wedge kinematics during extending convergent orogenesis of the northern Apennines, Italy: Geological Society of America Bulletin, v. 122, p. 1160-1179, doi:10.1130/B26573.1.

Treves, B., 1984, Orogenic belts as accretionary prisms: The example of the Northern Apennines: Ofioliti, v. 9 , p. 577-618.

Vannucchi, P., and Bettelli, G., 2002, Mechanisms of subduction accretion as implied from the broken formations in the Apennines, Italy: Geology, v. 30, p. 835-838, doi:10.1130/0091-7613(2002)030<0835:MOSAAI >2.0 .CO;2

Vannucchi, P., Remitti, F., and Bettelli, G., 2008, Geological record of fluid flow and seismogenesis along an erosive subducting plate boundary: Nature, v. 451, p. 699-703, doi:10.1038/nature06486.

Vannucchi, P., Remitti, F., and Bettelli, G., 2012, Latera variability of the erosive plate boundary in the Northern Apennines, Italy: Italian Journal of Geosciences, v. 13 , p. $215-227$.

von Huene, R., and Scholl, D.W., 1991, Observations at convergent margins concerning sediment subduction, subduction erosion, and the growth of continental crust: Reviews of Geophysics, v. 29, p. 279-316, doi:10.1029 /91RG00969.

von Huene, R., Ranero, C.R., and Vannucchi, P., 2004, Generic model of subduction erosion: Geology, v. 32, p. 913 916, doi:10.1130/G20563.1.

Zattin, M., Picotti, V., and Zuffa, G.G., 2002, Fission-track reconstruction of the front of the northern Apennine thrust wedge and overlying Ligurian unit: American Journal of Science, v. 302, p. 346-379, doi:10.2475/ajs.302.4.346.

Science Editor: Christian KoEberl

Associate Editor: Enrico Tavarnelu

MANUSCRIPT ReCEIVEd 28 JanUary 2012

Revised Manuscript Received 19 June 2013

MANUSCRIPT ACCEPTED 11 SePTEMBER 2013

Printed in the USA 